175 MALENE BREUNIG

Lektor

Institut for Kulturvidenskaber, Syddansk Universitet

\title{
HUMAN NATURE
}

\section{Terapihaven Nacadia som modernitetsretræte}

Midt i en klimakrisetid er der opstået en bemærkelsesværdig tiltro til naturen. Samtidigt med en globalt voksende erkendelse af naturen som betrængt pga. modernitetens ødelæggende rovdrift er der både kulturelt og videnskabeligt tendenser i retning af en slags gentilegnelse og genfortryllelse. Det vidner ikke kun udbredelsen af bæredygtige forbrugs- og livsstilsvalg om, men kommer også til udtryk inden for bl.a. den miljøpsykologiske og sundhedsantropologiske forskning. Naturen ses her som et attraktivt og ubetinget positivt ladet modstykke til det teknologisk avancerede, vækstorienterede og urbaniserede samfundsliv og hævdes i kraft heraf at kunne udgøre et refugium for fysisk og især mental sundhedspleje. Den forlenes med andre ord med en etisk-eksistentiel suverænitet og med en restaurativ funktion. Ved at give sig hen til naturen kan individet angiveligt vriste sig fri af kulturens lænker og øge livskvaliteten. Sådan konkluderes der bl.a. i Friluftsrådets nyligt gennemførte folkesundhedsprojekt "Sund i naturen"1. Og det er et bærende ræsonnementet i terapihaven Nacadia i

1 https://friluftsraadet.dk/vi-arbejder/friluftsliv-folkesundhed/sund-naturen. Projektet er evalueret i 2020 af bl.a. lektor ved Idræt og Biomekanik, SDU, Søren Andkjær. 
Arboretet ved Hørsholm, der siden 2011 har været forskningslaboratorium for naturbaseret restitutions- og rehabilitetsbehandling af bl.a. stressrelaterede lidelser. I det følgende gøres ræsonnementet til genstand for et kulturanalytisk casestudie.

Nacadias forståelse og brug af naturen som en helende kraft, der kan øge bevidstheden om krop og sjæl og derigennem aflaste eller ligefrem helbrede et svært stressplaget sind, forekommer umiddelbart både sympatisk og indlysende rigtig. Enhver, der i rekreativt øjemed søger og finder ro i naturen, vil formentlig kunne anerkende terapihavens principper. Ved nærmere eftertanke og læsning af konceptmanualen for Nacadia kan der imidlertid også opstå en vis skepsis, for kan naturens fysiske og især mentale indvirkning virkelig målrettes? Er der i den naturbaserede terapihave ikke indbygget et - måske utilsigtet - modsætningsforhold mellem instrumentalisering og romantisering? Dilemmaet diskuteres hverken i den alment tilgængelige formidling af Nacadia eller i de mange videnskabelige publikationer, der udspringer fra de tilknyttede forskere (f.eks. Corazon et al., Konceptmanual og Corazon et al., Stress, Nature \& Therapy). Skønt der faktisk findes en omfattende nyere forskningslitteratur om naturbaseret haveterapi, eller hvad man i den angelsaksiske tradition typisk omtaler som "therapeutic gardens" eller "healing gardens" (f.eks. Gerlach-Spriggs, Cooper Marcus \& Barnes og Cooper Marcus), er den næsten udelukkende orienteret mod terapeutisk praksis. Der savnes således et kulturanalytisk og dermed kritisk distanceret perspektiv på den naturbaserede terapihaves værdiladede præmisser.

Uagtet Nacadias eksistensberettigelse og relevans rettes opmærksomheden derfor her mod den naturopfattelse og samfundsdiagnose, stedet reproducerer. Ikke for at drage dets teoretiske fundament, metoder eller resultater i tvivl, men for at belyse nogle af de uekspliciterede/implicitte kultursammenhænge, det udspringer af. Det gør jeg ved først at udpege de grundlæggende principper for Nacadia, sådan som de dels er fremstillet i styregruppens konceptmanual, dels er udmøntet fysisk. Dernæst forholder jeg mig analytisk til Nacadias naturopfattelse og samfundsdiagnose, idet jeg argumenterer for to påstande: For det første at man opererer med en sproglig diskurs om og fysisk-æstetisk iscenesættelse af naturen som et 
fredfyldt og umiddelbart tilgængeligt sted for både selvfordybelse og samhørighed med 'noget større'. For det andet at iværksættelsen af et sådant reservat af romantisk tonede idéer og egenskaber tilskynder oplevelsesmodi, som for mennesker i et moderne samfund givetvis kan virke vederkvægende men også indebærer eller kan fremkalde et element af fremmedgørelse. Min tolkning af dette dilemma understøtter jeg vha. en perspektivering til to autobiografiske tekster, en romantisk og en moderne, der beretter om en dybfølt samfundslede og naturlængsel, som fører til det, Gregers Andersen har kaldt en "selvforandringens aktivisme". Teksterne giver således begge indblik i en drivkraft, som også Nacadias naturterapi bygger på, og samtidig repræsenterer de væsensforskellige erfaringer, der er historisk specifikke, men netop derved spejler, hvad jeg betragter som et skisma i Nacadia mellem ideal og virkelighed.

\section{DEN RESTAURATIVE NATUR}

Inden for de seneste ca. 30 år har man især blandt amerikanske miljøpsykologer fundet evidens for, at naturen under særlige former kan virke helbredende på nogle af de lidelser, som det moderne samfund fostrer (f.eks. Kaplan \& Kaplan og Ulrich). Denne forestilling om at kunne bringe sig på afstand af den sygdomsfremkaldende kultur og ud i en ufordærvet natur som led i et egentligt behandlingsforløb ligger til grund for etableringen af terapihaver, som er en paraplybetegnelse for haver og haveaktiviteter, der er tilrettelagt med henblik på, at syge mennesker kan opnå lindring eller helbredelse. Fænomenet findes i dag mange steder i verden, men har historiske forløbere i bl.a. klostre, tuberkulosesanatorier og psykiatriske hospitaler, som ikke blot af æstetiske men også sundhedsmæssige årsager ofte er blevet placeret i naturskønne omgivelser.

Nacadia er et dansk eksempel på et nyere naturterapeutisk haveanlæg, der i modsætning til en behandlingsform med fokus på det patogene traume udmærker sig ved at tage udgangspunkt i salutogenese. Frem for at søge dybere indsigt i de sygdomsfremkaldende årsagssammenhænge, lægger man således i stedet vægt på at styrke de menneskelige ressourcer og håndteringsstrategier, som kan fremme og stabilisere mental sundhed. 
178 KULTUR \& KLASSE *131*2021 SYGDOM

Psykoterapiens primære terapeutiske redskaber, samtalen og analysen af egne tanke- og handlemønstre, får dermed følgeskab af en opmærksomhed på kroppens 'væren-i-verden', idet fysisk tilstedeværelse og aktivering i naturmiljøer menes at stimulere sanseapparatet og skabe mentalt opløftende erfaringer af nærvær, velvære og meningsfylde. Under kyndig øvelsesbaseret vejledning er det f.eks. muligt for den alvorligt stressramte at få genoptrænet evnen til at mærke omgivelserne og navigere i dem på en rolig og afslappet måde. Ligeledes er det muligt at få skærpet bevidstheden om de fysiologiske og psykiske reaktioner, som kan være advarselssignaler om stress, f.eks. muskelspændinger, forhøjet puls, træthed, nervøsitet, koncentrations- og hukommelsesbesvær. Med denne holistiske forståelse af sundhed, som noget der indbefatter menneskets hele livssituation, kan Nacadia siges at praktisere WHOs brede sundhedsdefinition fra 1948. Hér slås det fast, at sundhed ikke blot er fraværet af sygdom, men en tilstand af både et fysisk, mentalt og socialt velbefindende, hvor individet kan udfolde sine evner, håndtere dagligdagsudfordringer og stress samt indgå i fællesskaber med andre mennesker. ${ }^{2}$

Målrettet sundheds- og plejesektoren er Nacadias godt 40 sider lange konceptmanual derfor også udarbejdet af en tværdisciplinær forskergruppe. Under navnet Natur, Sundhed \& Design og hjemmehørende ved Institut for Geovidenskab og Naturforvaltning, Københavns Universitet, varetager gruppen både de forsknings- og uddannelsesmæssige samt terapeutiske aktiviteter i tilknytning til Nacadia og tæller medarbejdere med baggrund inden for såvel landskabsarkitektur som pædagogisk og klinisk psykologi samt fysioterapi. Manualen gør rede for Nacadias tre metodisk-teoretiske grundpiller, der i praksis er forbundne og hævdes at have dokumenteret positiv effekt hos havens patientgrupper. For det første mindfulness meditation, der med rødder i buddhismen handler om på en bevidst måde at skærpe og fastholde opmærksomheden på øjeblikkelige impulser og sansninger, være til stede i nuet og acceptere det i stedet for at lade tanker og følelser søge frem og tilbage i tid mod enten ønske- eller rædselsscenarier.

2 https://www.sst.dk/da/opgaver/forebyggelse/indsatser/fokusomraader/ mental-sundhed 
For det andet kognitiv adfærdsterapi, hvor fokus er rettet mod en bevidstgørelse om uhensigtsmæssige adfærds- og handlemønstre mhp. at kunne omdirigere dem, dvs. skabe nye handlestrategier, der ikke er instrumentelle adfærdsmål, men snarere går ud på at lære at agere i overensstemmelse med personlige værdier og ressourcer. Og for det tredje naturbaseret terapi funderet i især de amerikanske miljøpsykologer Rachel og Stephen Kaplans omfattende undersøgelser af naturmiljøers restaurative egenskaber og deraf afledte "Attention Restoration Therapy" (177-200).

Sidstnævnte er selvsagt Nacadias særpræg. Udgangspunktet er Kaplan \& Kaplans grundlæggende tolkning af det moderne samfunds urbaniserede kultur som en slags trykkoger, der uafladeligt fordrer præstation og koncentreret opmærksomhed og derved avler overbelastningsskader som "mental fatigue". I forlængelse af denne antagelse er Nacadia derfor som både fysisk sted og terapeutisk praksis lagt an på en måde, der stimulerer sanselige oplevelser, skaber øget kropsbevidsthed og mental ro. Forudsætningerne herfor er, viser Kaplan \& Kaplans undersøgelser, at naturmiljøet vækker fascination og nysgerrighed, at det er fysisk adskilt fra forpligtelser i deltagerens dagligdag, at det har en udstrækning og et udtryk som understøtter følelsen af at være 'i en anden verden', og endelig at det er afstemt efter målgruppens ressourcer, præferencer og terapeutiske behov.

Det teoretiske fundament for udpegningen af disse kvalitative komponenter handler om, hvordan de specifikt kan bidrage til at fremme restitutionen og rehabiliteringen af det bebyrdede opmærksomhedssystem, der ifølge Kaplan \& Kaplan er todelt. For det første er vi som mennesker udstyret med en målrettet opmærksomhed ("directed attention"), der er aktiveret i alle rationelle sammenhænge, f.eks. når vi skal koncentrere os om en arbejdsopgave eller orientere os i trafikken, men det er en begrænset ressource som over tid sløves af informationsoverbelastning og medfører mental udmatning (179-182). For det andet er vi udstyret med en spontan opmærksomhed ("soft fascination"), som ikke er tidsbegrænset eller fokuseret på noget bestemt, men reagerer umiddelbart på indre og ydre stimuli (192). Utøjlet kan denne opmærksomhedsform bl.a. føre til koncentrationsbesvær, men teorien er, at hvis den rettes imod eller fanges ind af noget, der via sanseapparatet opleves som interessant, roligt og positivt, in casu 
et naturmiljø med de nævnte kvaliteter, vil det afslappe nervesystemet og genopbygge de mentale ressourcer til igen at kunne bruge den målrettede opmærksomhed.

Nacadias godt og vel 14.000 kvadratmeter er derfor opdelt i afgrænsede rum, der hver især søger at fremme specifikke rekreative og restaurative oplevelsesværdier. Det overordnede indtryk er en skovhave omkranset af arboretets fredede botaniske artsrigdom i et kuperet terræn, hvor arealer med varierede proportioner, kontrastrige vegetationsmønstre og grader af åbenhed tilbyder både vidtstrakte panoramiske rum, der åbner sig enten vertikalt eller horisontalt, og afgrænsede tableauer med en mere intim atmosfære. De pastoralt anlagte rum og prospekter inviterer til stille eftertænksomhed og terapeutisk samtale, mens havens hortikulturelle rum giver mulighed for mere fysisk krævende og sociale aktiviteter. ${ }^{3}$ Afhængigt af årstid og vejrlig kan man f.eks. tage del i røgt og pleje af planter, bier og bygninger, høst af afgrøder, træfældning, brændehugning og brødbagning over bål. Digitale gadgets og andet opmærksomhedsforstyrrende grej er bandlyst, og overalt hviler der en analog æstetik, idet menneskeskabte faciliteter konsekvent er holdt i naturlige materialer, former og farver, som var de groet naturligt ud af omgivelserne.

Der lægges således op til forskellige grader af indadvendt og udadvendt engagement samt nærvær, refleksion og aktiv involvering. Uanset hvordan den enkelte deltager vælger eller opfordres til at interagere med omgivelserne tilstræbes det dog overalt at tilvejebringe oplevelser af meningsfylde, forståelighed og håndterbarhed, fordi det skaber tryghed og fremmer psykisk robusthed, ligesom det giver en "følelse af sammenhæng i livet" (Corazon et al., Konceptmanual 20). Nacadias gestaltning af en sådan både "skærmet og udstrakt anden verden, der er forskellig fra hverdagen" (18) fordrer imidlertid ikke kun en fysisk og mental tilstedeværelse, men også en særlig indlevelse, som knytter an til en form for naturfilosofisk organismetænkning og i konceptmanualen formuleres på følgende måde:

3 Den pastorale og den hortikulturelle have er betegnelser for hhv. den åbne landskabshave og det dyrkede og indhegnede grosted (Hauxner 22). 


\section{MALENE BREUNIG}

HUMAN NATURE

I naturen er eksistentielle temaer bogstaveligt talt til stede; vi oplever livets begyndelse med de spirende frø og forårets komme, og døden eller dvalen om efteråret. Disse oplevelser kan integreres i refleksioner over livet. Eksempelvis kan tanker om personlig stabilitet og vækst relateres til træets rodsystem, der giver det styrke til at holde stammen og udfolde kronen. Naturen er derfor et miljø, der kan fungere som et spejl, hvor vi kan relatere til vores egen eksistens og problematikker. (16-17)

\section{ROMANTISK GENFORTRYLLELSE}

Hvad man måske kunne opfatte som forfatternes sproglige poetisering af Nacadias koncept skal snarere forstås som et nøgternt udtryk for forfatternes natursyn. Afvigende fra en udbredt antropocentrisk holdning i moderniteten, hvor mennesket betragter sig selv som hersker over en uhellig natur med suveræn ret til at udnytte den til egne formål, lægges der op til en anderledes ydmyg tilgang. Hvad enten naturen er vild og uberørt eller tæmmet og arrangeret udgør den i Nacadia-forskernes optik et særegent rum, hvis egenskaber og processer kan tolkes som billeder på menneskelige følelses- og bevidsthedstilstande. Brugen af de terapeutiske metaforer og narrativer, som naturen stiller til rådighed, handler om at ville konkretisere deltagerens forståelse og accept af sig selv i samhørighed med naturens vækstprocesser og årstidernes cykliske rytme, dvs. gøre en abstrakt betydningssammenhæng mere konkret og begribelig. Havens bearbejdede og iscenesatte natur, dens mimen af den 'rigtige' natur i en koncentreret, æstetisk appellerende form, forstås således ikke bare som en mere indbydende og antiautoritær kulisse for terapeutisk behandling end den konventionelle konsultations disciplinerede rammer. Den antages først og fremmest at være en levende organisk helhed, som spejler nogle menneskelige grundvilkår og herved tilbyder et eksistentielt fodfæste.

Terapihavens natur-lighed bliver herved en genfortryllet verden, hvis implicitte modbillede er den afsjælede og åndløse kulturs formålsbestemte og dog uigennemskuelige sammenhænge. Der er elementer af det romantiske haveanlægs gennemkoreograferede oplevelseskoordinater, som man f.eks. kender fra Sanderumgaards Have på Fyn, hvor snurrige gemmesteder, symbolske monumenter og rum for refleksion over eksistensen oprindeligt havde til hensigt at stimulere den følsomme vandrer 
182 KULTUR \& KLASSE *131*2021 SYGDOM

og bibringe ham vekslende stemningstilstande (Knudsen 352). Og det er også lige før F.W.J. Schellings (1775-1854) aforisme om ånden, der slumrer i stenen, drømmer i planten, vågner i dyret og kommer til bevidsthed $\mathrm{i}$ mennesket, klinger med i citatet ovenfor. Men Nacadia genopfører selvsagt ikke den romantiske haves teateragtige iscenesættelse som en yndefuld og malerisk landlig idyl, der vækker sentimentale følelser, og er heller ikke indforskrevet i en universalromantisk naturfilosofi. Udgangspunktet er i stedet, at mennesket er et biologisk væsen, der er forbundet med såvel naturens som det æstetisk planlagte kulturlandskabs vegetative dyre- og planteliv. Og hensigten er, at mennesket ved at blive fortrolig med naturen får bragt den sanselige umiddelbarhed og frie følelsesstrøm til live, som modernitetens teknisk-økonomiske rationalitet træder under fode. Skønt Nacadia i sit navn associerer til arkadien, der i klassisk forstand er et digterisk ophøjet landskab, hvor fredeligt hyrdeliv og paradisisk uskyld hersker, er det således ikke en abstrakt idealisering af naturen som en oprindelig og autentisk værenstilstand, man prøver at opdyrke. Tværtimod opereres der ud fra den hypotese, at naturen både i sig selv og som rum for kontemplation, samtale og fysisk aktivitet kan bibringe erfaringer, der findes i det konkrete og erkendelser, der kun gives adgang til via sanseapparatet og indlevelses- eller forestillingsevnen.

Betingelserne for Nacadias terapeutiske koncept er altså en tro på, at vi som mennesker er generisk forbundet med naturen, at naturen udgør en helende kraft for så vidt, der drages omsorg for den, og at naturen er (eller kan forvaltes som) en slags semiotiske rum og billeder, man kan træde ind i og aflæse betydning af. De 'tegn', Nacadias deltagere møder, kredser derfor om samme symbolik: den skønhed og harmoni, der eksisterer, når mennesket (tilsyneladende) ikke bryder forstyrrende ind i naturens processer, men blot diskret sætter dem i scene, fæstner sig i kroppen som roligere pulsslag og løfter sindet fri af tankemylder. En sådan eksemplarisk oplevelsesmodus indebærer imidlertid foruden en modtagelighed og sensibilitet også evnen til æstetisk påskønnelse, hvis referent næppe kan siges alene at være mødet med den fysiske natur. Den har, vil jeg påstå, rødder i et både romantisk og økokritisk narrativ om den livskraftige natur som et sundhedens, sandhedens og uafhængighedens topos. 


\section{MALENE BREUNIG}

HUMAN NATURE

Nacadias natursyn er med andre ord tvetydigt. På den ene side bekender man sig til en moderne bevidsthed om, at naturen aldrig byder sig til i absolut ren form, idet den i vores tilegnelse altid i én eller anden forstand er rammesat og valoriseret. Ikke kun når vi oplever den gennem tekst og billeder i eksempelvis litteratur, film og på tv, men også når vi oplever den in situ, hvor vores bevidsthed uundgåeligt er farvet af de medialiserede og æstetiserede fremstillinger, ligesom den er ansporet af menneskeskabte vandreruter, udsigtspunkter, hvilesteder etc. For så vidt er Nacadias raison d'être slet ikke den selvberoende natur, men derimod en medieret eller kultiveret natur, som er formålsbestemt, idet den erklærede hensigt jo netop er at opnå terapeutisk effekt til gavn for samfundet og den enkelte. På den anden side bekender man sig indirekte til en kulturpessimisme, som allerede vandt indpas under modernitetens fremvækst i 1800-tallet og bl.a. kom til udtryk i litteraturen, hvor forfattere begyndte at lovprise naturen som et autenticitetens værested. Det skal jeg i det følgende prøve at uddybe med et perspektiverende eksempel fra amerikansk såkaldt transcendentalisme.

\section{DET ER SAMFUNDETS SKYLD}

I forestillingen om terapihaven som et reservoir af gode, sande og skønne egenskaber med potentielt sundhedsfremmende virkning ligger der indbygget en kritisk samfundsdiagnose. Selvom konceptmanualen om Nacadia beskriver den hybride naturterapis teori og praksis uden at nævne, hvad der kunne tænkes at være årsag til de behandlingskrævende stresstilstande og angstlidelser - muligvis pga. det erklærede salutogene udgangspunkt - så taler den konsekvente distancering af modernitetens urbaniserede, kapitaliserede og digitaliserede livsrum dog sit eget tydelige sprog. Det skyldes selvsagt, at ethvert natursyn nødvendigvis udspringer af en historisk og kulturelt betinget kontekst, eller som litteraturprofessor Svend Erik Larsen har udtrykt det, at "vejen tilbage til naturen slet ikke [er] bestemt af den natur den fører frem til, men af den kultur den fører væk fra" (161).

Retter vi derfor opmærksomheden mod Nacadias uudtalte præmis, mod dét naturterapien synes at være formuleret op imod, kan forfatteren Henry David Thoreau (1817-1862) hjælpe os med at forstå, hvad der er på 
184 KULTUR \& KLASSE * $131 * 2021$ SYGDOM

færde. Som en overgangsfigur mellem en romantisk og moderne eksistenstænkning var Thoreau netop optaget af at revitalisere den umiddelbare naturoplevelse som en terapeutisk modgift til kulturen, der efter hans opfattelse var i moralsk forfald og som en sygdom angreb menneskets tanke- og følelsesliv. "'Nature' is but another name for health", konstaterede han i sin dagbog i 1853, og det var med fuld personlig erfaringsdækning, kan man læse i hans autobiografiske robinsonade Walden; or Life in the Woods, der udkom året efter. Som digterfilosof og kritiker af det hektiske samfundsliv havde Thoreau i en toårig periode sat sig for at praktisere, hvad han før kun havde prædiket, nemlig at hvis man anskaffer mere, end man har brug for, så ejer man ikke tingene, men er blevet slave af sine ejendele. Ved at vende ryggen til bylivet og bosætte sig i en selvbygget hytte ved Walden Pond omgivet af store skove ville han manifestere en løsrivelse fra kulturskabte idealer om effektivitet, fremdrift og materiel stræben for i stedet at leve et liv i nøjsomhed og med tid og rum til eftertænksomhed. På nudansk livsstilslingo kalder vi det "simple living", men hos Thoreau var målet ikke kun at kompleksitetsreducere tilværelsen ved at skære alt unødigt fra. Han ville skabe et reelt alternativ til kapitalismens idealer om rationel arbejdsdeling, masseproduktion og ejendomsbesiddelse og søge svar på livets mål og mening i naturen, fordi den i hans optik stadig repræsenterede en uspoleret verden helt renset for kunstige behov og oplevelsesstimuli. Som selvbestaltet eremit praktiserede han dermed sin tro på, at en dybere selvindsigt og frihedsfølelse er betinget af, at mennesket tager kritisk stilling til den herskende kulturs dekorum og anerkender naturens gådefulde livskraft. ${ }^{4}$

I Thoreaus beretning kan man således læse, hvordan han studerede dyrelivets sælsomme adfærdsmønstre og udforskede skoven og søens forvandling under årstidernes vekslen og vejrets skiftende luner. For at

4 Min perspektivering til Thoreaus kanoniserede værk bygger her på en mere udfoldet historisk læsning i min artikel "Naturen kalder - skoven som romantisk og moderne tilflugtssted", hvor jeg sammenligner hans fremstilling af skoven som øko-eksistentielt motiv med Andrea Hejlskovs ditto i hendes bog og den store flugt, som i nærværende artikel også inddrages perspektiverende lidt længere fremme. 


\section{MALENE BREUNIG}

HUMAN NATURE

brødføde sig selv behøvede han kun at arbejde ganske lidt og fik derfor tid og overskud til at opøve sin mentale tilstedeværelse i naturen, hvad der efterfølgende hjalp ham til at kunne nedfælde sine oplevelser. Skønt det bogførende fortællerjeg både i tid og rum befandt sig på afstand af det fortalte, forvandlede hans erindring dog ikke det oplevede til et paradis på jord. Naturen fremtræder ikke disneyficeret, men er skildret i overensstemmelse med oplevelsestidspunktets skarpt sansede og usentimentale tilegnelse. Den er både storslået og smuk, rå og brutal, larmende tavs og uudgrundelig, men så meget desto mere betydningsladet og oplivende. Hvad Thoreau opdagede under sit eksil, forbinder ham således med den idealforestilling, Nacadia hviler på og sætter i scene: nærheden til naturen skærper en samhørighedsfølelse og styrker en livsduelighed, som i samfundslivet glider mennesket af hænde.

Selvom det både hos Thoreau og i Nacadias koncept er naturen, der på én gang løfterigt og fordringsfuldt hævdes at være meningsgivende og helbredende, er det lige så meget fraværet af det urbane miljø, som medvirker hertil. Behovet for at bearbejde alvorlige stresssymptomer kan naturligvis være affødt af forskellige omstændigheder, men den udbredte krisetilstand, der populært går under betegnelsen udbrændthed og betragtes som en trussel mod folkesundheden, har, må man formode, sit ophav i en samfundsgenereret afmagtsfølelse. Det har ikke kun den kliniske stressforskning påpeget, men er også en kulturanalytisk diagnose, som bl.a. Bruno Latour har stillet (2). I forlængelse af den kritiske teoris tradition for at identificere og tolke den menneskelige mistrivsel i kølvandet på urbaniseringen, industrialiseringen, digitaliseringen og globaliseringen, adresserer han netop den følelse af udmattelse og hjælpeløshed, der viser sig i diagnoseboom og desperat længsel efter at kunne stå af ræset. Den kapitalistiske logik, som gennemsyrer moderniteten, er ifølge Latour blevet et så stærkt dogme i vores vestlige kultursfære, at den altid opfattes som om, den har en suveræn eksistensberettigelse. Vækst- og konkurrencelogikken er blevet en mentalitet, et internaliseret værdikodeks og navigationssystem, der går forud for alt andet, også hensynet til klodens økosystemer og menneskers mentale sundhed. Ifølge Latour skaber modernitetens kapitalistiske styreform dermed ikke kun et umenneskeligt præstationspres, men producerer 
186 KULTUR \& KLASSE *131*2021 SYGDOM

også usikre, handlingslammede og resignerede individer uden tro på, at de selv kan bestemme deres livsbane og gøre en positiv forskel (9).

\section{HELINGSIDEAL OG SPALTNINGSVILKÅR}

Inspireret af bl.a. Latour har litteratur- og kulturforsker Gregers Andersen i debatbogen Grænseløshedens kultur. Et opgør med hastighed, udmattelse og håbløshed $i$ klimakrisens tidsalder mere specifikt adresseret konsekvenserne af den sene modernitets konkurrencestatslogik. Dens "vækstimperativ" og "hastighedsregime" har medført "et sammenbrud i skellet mellem arbejdsliv og privatliv" og finder sin "følelsesmæssige forankring i frygten for at miste velstand" (55). Men til trods for alvorlige menneskelige omkostninger som kronisk utilstrækkelighedsfølelse og nedslidning med deraf forbundet tab af arbejdsfortjeneste og udgifter til rehabilitering, er det imidlertid et vilkår, som er forblevet stort set uantastet. Nacadia beror på en lignende samtidsdiagnose og tilbyder med sin naturterapi en kur eller helbredelsesmulighed, som appellerer til det personlige initiativ og engagement, som også Gregers Andersen fæstner sin lid til:

Hvis hjælpeløsheden [...] er en af de primære affekter i vores tid, vil jeg insistere på, at det stadig er muligt at finde håb i den personlige aktivisme. For der ligger i den energi, der konstituerer selvforandringens aktivisme en følelsesmæssig befrielse fra den apati, som er forløberen for den fuldstændige hjælpeløshed. Hjælpeløsheden vil ganske vist stadig vise sig som en del af vores affektive register, [...] men den personlige aktivisme vil også rumme et håb: Et håb om, at andre ligeledes vil ændre sig og dermed ændre de kulturer, som i sidste ende giver føde til de politiske og økonomiske systemer. (30)

Den forsigtige optimisme hos Gregers Andersen er foranlediget af den kritiske opposition til det bestående, som i disse år kommer til udtryk i den aktivistiske klimadebat og i udviklingen af bæredygtige løsninger til gavn for klodens økosystemer. Denne vilje til forandring af indgroede livsvaner og forbrugsmønstre er dog næppe kun motiveret af et ansvar for påtrængende globale kriser, men nok så meget af netop de uopsættelige individuelle eksistensforhold, Gregers Andersen påpeger, og som Nacadia søger at imødekomme. Nacadia repræsenterer netop en anerkendelse af 


\section{MALENE BREUNIG}

HUMAN NATURE

det menneskelige behov for, i det mindste momentvist, at kunne retirere ind i et rum, hvor det er muligt at finde eller selv skabe den ro, langsomhed og fordybelse, som har svære eller helt umulige betingelser i det omgivende samfund. Naturen er helt oplagt en sådan retræte. Den retter ikke kun opmærksomheden væk fra de arbejds- og livssammenhænge, hvori de 'u-naturlige' krav og forventninger har råderum, som skaber kognitiv dissonans og fysisk ubehag. Den rummer angiveligt også en uspoleret urkraft, der kan bringe mennesket i kontakt med sin indre styrke og derved øge den mentale sundhed.

Nacadia tilbyder dog herved alene en individualiseret sygdomsbekæmpelse, tilpasset og til gavn for den enkelte, mens mistrivslens kollektive årsagssammenhænge til stadighed består. Erkendelsen er tilsyneladende, at den kapitalistiske samfundsmodel næppe står for fald, men dermed bliver naturterapien også kun en slags symptombehandling, et plaster på såret. I mere udvandede aftapninger ser man da også aktuelt eksempler blandt kapitalismens egne drivkræfter på brugen af naturen som en personaleplejende foranstaltning. I forbindelse med opførelsen af et nyt hovedsæde i 2014 afsatte medicinalvirksomheden Novo Nordisk betydelige ressourcer til at lade arkitektfirmaet SLA, der er specialiserede i bæredygtige fysiske trivselsmiljøer, etablere et større grønt område med en høj grad af biodiversitet omkring domicilet. I stedet for den slags velfriserede anlæg, man typisk ser ved større virksomheder, har man derved sørget for, at medarbejderne dagligt får lejlighed til at bevæge sig uden for og ad slyngede stier få pirret sanserne gennem en mangfoldighed af fyrre- og løvtræer, buske og blomster. Anlægget skaber desuden mulighed for såkaldte walk \& talk-møder og for rekreative pauser. Latour og andre kapitalismekritikere ville selvfølgelig indvende, at kalkulen i et sådant ressourceopbud er, at det i sidste ende skaber øget profit og netop overlader trivselsansvaret til den enkelte. Men bemærkelsesværdigt er det trods alt, at den rationelle cost-benefit-analyse her omfatter anerkendelsen af naturen - selv i et begrænset format - som en saliggørende kraft.

Tilbage står imidlertid spørgsmålet, om det er muligt for det moderne menneske at møde naturen så uhildet og tillidsfuldt, som det tilsyneladende lod sig gøre for romantikeren Thoreau. Er det en realistisk antagelse, 
188 KULTUR \& KLASSE *131*2021 SYGDOM

at alle og enhver vha. terapeutisk vejledning kan opnå en slags indvielse og renselse i naturen? Spørgsmålet kan lyde retorisk, måske endda polemisk, men mine forbehold skyldes, at selv med nok så stor sympati for den naturbaserede terapi, synes dens fysisk-æstetiske rammesætning som et reservat af antimodernitet at skabe en både kunstig og uhensigtsmæssig natur-kultur-dualisme. Dels fordi forvaltningen af naturen som et ophøjet rum for 'sunde' identiteter på afstand af politik, økonomi og kultur reproducerer en slags ønskeforestilling, der fortrænger vores instrumentelle forhold til naturen. Dels fordi det moderne livs nedslag i krop og sind ikke kan undslippes, uanset hvor meget vi prøver at give os hen til naturen og eventuelt underkaster os den med en asketisk og primitiv livsstil à la den, Thoreau praktiserede.

Det er dilemmaer, som mange forfattere har adresseret i generationer. En del har ganske vist hyldet en slags helende naturfølelse. Det gælder bl.a. Jeppe Aakjær, Thøger Larsen, Thorkild Bjørnvig, Vagn Lundbye, Inger Christensen og Josefine Klougart. Men andre har netop problematiseret det moderne kultur-utilpassede menneskes længsel 'tilbage' til naturen som et forjættet land, f.eks. Henrik Pontoppidan i romanerne Lykke-Peer (18981904) og De dødes rige (1912-16). Endvidere har en økopoesi med udgangspunkt i en kritik af den antropocæne tænknings fatale indvirkning på klima og miljø i de senere år ført til mere eller mindre dystopiske naturbilleder i bl.a. Lars Skinnebach, Caspar Eric, Liv Sejrbo Lidegaard og Theis Ørntofts forfatterskaber. Og denne afmagt over for et (verdens)samfund, som har fortrængt og ødelagt naturen og dermed skabt grobund for en ubændig længsel efter og idealisering af den, skildres også i forfatteren og bloggeren Andrea Hejlskovs (f. 1975) personlige beretning og den store flugt (2013). Bogens litterære værdi kan nok diskuteres, men som vidnesbyrd om en voldsomt stressplaget familie, der netop forfølger drømmen om at finde ro og harmoni i naturen, er den bemærkelsesværdig, fordi den viser, hvor vanskeligt det er at få drømmen til at gå i opfyldelse. Ulykkelige og desperate over at være kørt psykisk ned af velstandssamfundets endeløse forpligtelser og forventninger vælger familien flugten og bosætter sig som nybyggere i en øde svensk skov. De vil trodse alt det, der har skabt fornemmelsen af på én gang at være handlingslammede og i konstant alarmberedskab, og for 
at eliminere afhængigheden af samfundet gennemfører de deres fortsæt med kun basale fornødenheder til rådighed og selvforsyning for øje. Trods denne "selvforandringens aktivisme" må jeg-fortælleren Andrea imidlertid sande, at den fysiske og især mentale selvberoenhed, hun håbede og troede at naturen kunne bibringe, kun indfinder sig sporadisk.

Hvad der i et tolkningsperspektiv knytter netop denne beretning til Nacadia er, at naturen ikke nødvendigvis byder sig til som et slags selv-opbyggeligt spejlkabinet, men kan opleves som et afvisende og uindtageligt territorium. Protagonisten Andrea kæmper forgæves for at opnå en stabil og harmonisk samhørighedsfølelse med sine nye omgivelser, men må sande, at hverken hendes psykologuddannelse eller kritiske (selv)bevidsthed kan bruges til noget i naturen. Det er kompetencer som ingen gyldighed eller status har her, men alene udgør en hæmsko. Hvor Thoreau kunne tilegne sig naturen romantisk-vitalistisk som 'wild and free', er Andrea nemlig definitivt præget af modernitetens double-bind. Hun oplever at være fremmedgjort over for den natur, hun samtidig uophørligt længes efter at forbinde sig med.

Selvom Nacadia ikke i samme grad lægger op til en sammensmeltning med naturen, peger Andreas historie altså på et dilemma, hun næppe er alene om. Uagtet hvor meningsfuldt det forekommer at bringe sig tættere på naturen og interagere med den på måder, som kan virke helende, så er spaltningen mellem krop og bevidsthed et vilkår, der står i vejen herfor. Det moderne individs (selv)refleksivitet kan være et tyngende åg, der er umuligt at krænge af sig, og som ikke blot forhindrer den eftertragtede mentale opløftelse og sanselige henrykkelse men også tilvejebringelsen af en styrket livsduelighed. Selvom Nacadias idégrundlag og narrativ er tværfagligt funderet i en både bred og dyb viden om naturens terapeutiske potentiale, kunne det således med fordel udvides. Der synes at mangle et kulturhistorisk og -analytisk perspektiv, som kritisk belyser og evt. korrigerer nogle af de implicitte antagelser og ideale fordringer om forbindelsen mellem menneske og natur.

MALENE BREUNIG, ph.d., lektor ved Institut for Kulturvidenskaber, Syddansk Universitet. Har i bøger, tidsskrifter og antologier især skrevet om forholdet mellem intimitet og modernitet i et kulturhistorisk og tværæstetisk perspektiv, bl.a. i bogen Den iscenesatte bolig. 
190 KULTUR \& KLASSE *131*2021

SYGDOM

Fem studier om hjemliggørelse i det 20. århundrede (Odense: Syddansk Universitetsforlag, 2016). Seneste publikationer handler om det modernitetsubehag, der aktuelt viser sig i danskernes hypede hyggekultur og æstetiske dyrkelse af en mytologiseret nordisk natur.

\section{HUMAN NATURE}

The Healing Garden Nacadia as a Retreat from Modernity

The research-based Danish therapy garden Nacadia, which opened in 2011, can be viewed as a holistically oriented realization of the World Health Organization's (WHO) broad definition of health from 1948: health is not just the absence of disease, but a state of both physical, mental and social well-being in which individuals may develop their abilities, deal with everyday challenges and stress, as well as socialize with other people. Nacadia's raison d'être and relevance are indisputable. But the questions this article addresses are what perception of nature the therapy forest garden promotes and what social diagnosis it springs from and reproduces. Nacadia's interdisciplinary research team provides no explanation, but these questions inform my analysis. Based on Nacadia's concept manual and the therapy garden itself, as well as some literary accounts of engaging with nature, I develop two answers: First, that the researchers behind Nacadia operate with both a discourse and a physical-aesthetic presentation of nature as a peaceful and accessible place for both self-immersion and connection with 'something greater'. Secondly, the implementation of such a sanctuary encourages romantically tinted modes of experience which certainly seem invigorating but may also evoke an element of alienation for people in a modern society.

\section{KEYWORDS}

DA: Naturterapi; natur-kultur-dualisme; naturromantik; modernitetskritik; folkesundhed

EN: Nature based therapy; nature-culture duality; romanticism and modernity; public health 


\section{MALENE BREUNIG}

HUMAN NATURE

\section{LITTERATUR}

Andersen, Gregers. Grænseløshedens kultur. Et opgør med hastighed, udmattelse og håbløshed $i$ klimakrisens tidsalder. København: Informations Forlag, 2016.

Breunig, Malene. "Naturen kalder. Skoven som romantisk og moderne tilflugtssted". Læsninger på tværs. Red. Lars Handesten et al. Hellerup: Spring, forventet publicering forår 2021.

Cooper Marcus, Clare og Marni Barnes. "Introduction: Historical and Cultural Perspective on Healing Gardens". Healing Gardens. Therapeutic Benefits and Design Recommendations. Red. Clare Cooper Marcus og Marni Barnes. New York: John Wiley \& Sons, 1999.

Cooper Marcus, Clare. "Gardens and Health". Design \& Health. The Therapeutic Benefits of Design. Red. Alan Dilani. Stockholm: Svensk Byggtjänst, 2001.

Corazon, Sus S., Theresa S.S. Schilhab og Ulrika K. Stigsdotter. "Developing the therapeutic potential of embodied cognition and metaphors in nature-based therapy: lessons from theory to practice". Journal of Adventure Education \& Outdoor Learning 112 (dec. 2011): 161-171.

Corazon, Sus S. Stress, Nature \& Therapy. Frederiksberg: Forest \& Landscape, Københavns Universitet, 2012.

Corazon, Sus S. et al. "Konceptmanual for Nacadias naturbaserede terapi". Institut for Geovidenskab og Naturforvaltning, Københavns Universitet. 2018. 22. september $2020<$ https://ign.ku.dk/terapihaven-nacadia/>.

Gerlach-Spriggs, Nancy, Richard Enoch Kaufman og Sam Bass Warner, Jr. Restorative Gardens. The Healing Landscape. New Haven and London: Yale University Press, 1998.

Hauxner, Malene. Fantasiens have. Det moderne gennembrud i havekunsten og sporene $i$ byens landskab. Kbh.: Arkitektens Forlag, 1993.

Kaplan, Rachel og Stephen Kaplan. The Experience of Nature. A Psychological Perspective. Cambridge: Cambridge University Press, 1989.

Knudsen, Karin Esmann. Paradis på jord. Havernes kulturhistorie. Kbh.: U Press, 2019.

Larsen, Svend Erik. Naturen er ligeglad. Naturopfattelser i kulturel sammenhæng. Kbh.: Munksgaard/Rosinante, 1996.

Latour, Bruno. "On some of the affects of capitalism", 2014. Web 10. november 2020. <http:// www.bruno-latour.fr/sites/default/files/136-AFFECTS-OF-K-COPENHAGUE.pdf>.

Thoreau, Henry David. Walden; or, Life in the Woods. Boston: Ticknor and Fields, 1854.

Ulrich, Roger S. "Effects of Gardens on Health Outcomes: Theory and Research". Healing Gardens. Therapeutic Benefits and Design Recommendations. Red. Clare Cooper Marcus og Marni Barnes. New York: John Wiley \& Sons, 1999. 
192 KULTUR \& KLASSE *131*2021 SYGDOM 